\title{
Associations of plasma uric acid and purine metabolites with blood pressure in children
}

Citation for published version (APA):

Scheepers, L. E. J. M., Boonen, A., Pijnenburg, W., Bierau, J., Staessen, J. A., Stehouwer, C. D. A., Thijs, C., \& Arts, I. C. W. (2017). Associations of plasma uric acid and purine metabolites with blood pressure in children: the KOALA Birth Cohort Study. Journal of Hypertension, 35(5), 982-993.

https://doi.org/10.1097/HJH.0000000000001270

Document status and date:

Published: 01/05/2017

DOI:

10.1097/HJH.0000000000001270

Document Version:

Publisher's PDF, also known as Version of record

Document license:

Taverne

Please check the document version of this publication:

- A submitted manuscript is the version of the article upon submission and before peer-review. There can be important differences between the submitted version and the official published version of record.

People interested in the research are advised to contact the author for the final version of the publication, or visit the DOI to the publisher's website.

- The final author version and the galley proof are versions of the publication after peer review.

- The final published version features the final layout of the paper including the volume, issue and page numbers.

Link to publication

\footnotetext{
General rights rights.

- You may freely distribute the URL identifying the publication in the public portal. please follow below link for the End User Agreement:

www.umlib.nl/taverne-license

Take down policy

If you believe that this document breaches copyright please contact us at:

repository@maastrichtuniversity.nl

providing details and we will investigate your claim.
}

Copyright and moral rights for the publications made accessible in the public portal are retained by the authors and/or other copyright owners and it is a condition of accessing publications that users recognise and abide by the legal requirements associated with these

- Users may download and print one copy of any publication from the public portal for the purpose of private study or research.

- You may not further distribute the material or use it for any profit-making activity or commercial gain

If the publication is distributed under the terms of Article $25 \mathrm{fa}$ of the Dutch Copyright Act, indicated by the "Taverne" license above, 


\title{
Original Article
}

\section{Associations of plasma uric acid and purine metabolites with blood pressure in children: the KOALA Birth Cohort Study}

\author{
Lieke E.J.M. Scheepers ${ }^{a, b}$, Annelies Boonen ${ }^{a, b}$, Wieke Pijnenburg ${ }^{c}$, Jörgen Bierau ${ }^{d}$, \\ Jan A. Staessen ${ }^{c, e}$, Coen D.A. Stehouwer ${ }^{f, g}$, Carel Thijs ${ }^{b, c}$, and Ilja C.W. Arts ${ }^{c, h}$
}

\begin{abstract}
Objective: Elevated serum uric acid concentration has been associated with high blood pressure (BP) and hypertension. A putative underlying mechanism is the accumulation of reactive oxygen species when uric acid is generated by an increased enzyme activity of xanthine oxidase $(\mathrm{XO})$. The aims of the present study were to investigate the associations between plasma uric acid concentration, purine metabolite ratios, as proxies for increased XO activity, and SBP and DBP in school-age children.
\end{abstract}

Methods: Cross-sectional analyses were performed in 246 children (46\% boys; mean age 7.1 years) from the Dutch KOALA Birth Cohort Study. Purine metabolites were determined with ultra-performance liquid chromatography-tandem mass spectrometry. During a home visit, a nurse collected a blood sample and measured BP three times; in addition, parents measured their child's BP on three consecutive days, in the morning and evening. Generalized estimating equations were used for analyses while controlling for variables such as sex, age, BMI, physical activity, and dietary intake.

Results: In multivariable analysis, uric acid (per SD of $38 \mu \mathrm{mol} / \mathrm{l})$ was associated with DBP $z$-scores [s $\beta$ 0.07; confidence interval (CI), 0.01-1.14], but not with SBP $z-$ scores. Higher ratios of uric acid/xanthine (per SD of 138) (s $\beta$ 0.09; $\mathrm{Cl}, 0.01-0.17$ ) and xanthine/hypoxanthine (per SD of 321) (s $\beta 0.08 ; \mathrm{Cl}, 0.02-0.17)$ were associated with higher DBP $z$-scores, but not with SBP $z$-scores.

Conclusion: In school-age children, uric acid and the ratios of uric acid/xanthine and xanthine/hypoxanthine were significantly associated with DBP z-scores. Suggesting that, both uric acid concentration and increased $X O$ activity are associated with BP.

Keywords: blood pressure, blood pressure z-scores, children, hypertension, hypoxanthine, uric acid, xanthine, xanthine dehydrogenase, xanthine oxidase, xanthine oxidoreductase

Abbreviations: $\mathrm{BP}$, blood pressure; $\mathrm{Cl}$, confidence interval; eNOS, endothelial nitric oxide synthase; FFQ, food frequency questionnaire; GEE, generalized estimating equations; HGPRT, hypoxanthine-guanine phosphoribosyltransferase; IMP, inosine monophosphate;
IQR, interquartile range; KOALA, Kind, Ouders en gezondheid: Aandacht voor Leefstijl en Aanleg (A Dutch acronym for child, parents and health: lifestyle and genetic constitution); $N A D(P) H$, nicotinamide adenine dinucleotide (phosphate) (reduced form); NHBPEP, National High Blood Pressure Education Program; NO, nitric oxide; PPGP, pregnancy-related pelvic girdle pain; ROS, reactive oxygen species; UA, uric acid; XO, xanthine oxidase; XOR, xanthine oxidoreductase

\section{INTRODUCTION}

$\mathrm{R}$ ecent meta-analyses show that elevated serum uric acid concentration increase the risk of incident hypertension among adults, independent of traditional risk factors [1,2]. Associations were significantly stronger in younger adults and tended to be larger in women, but studies among individuals younger than 18 years of age were not included in these meta-analyses [2]. During the past several years, a number of studies assessed this association in older children and adolescents, and extended evidence for elevated blood pressure (BP) and hypertension among those with elevated serum uric acid concentration to this age group (summarized in Table 1).

Several mechanisms have been proposed that causally link uric acid with hypertension. For example, uric acid

\section{Journal of Hypertension 2017, 35:982-993}

aDivision of Rheumatology, Department of Internal Medicine, Maastricht University Medical Centre, ${ }^{b}$ CAPHRI School for Public Health and Primary Care, 'Department of Epidemiology, Maastricht University, dDepartment of Clinical Genetics, Maastricht University Medical Centre, Maastricht, The Netherlands, ${ }^{2}$ Research Unit Hypertension and Cardiovascular Epidemiology, KU Leuven Department of Cardiovascular Diseases, Studies Coordinating Centre, University of Leuven, Leuven, Belgium, 'Department of internal medicine, Maasticht University Medical Center, ${ }^{9}$ CARIM School for Cardiovascular Diseases, Maastricht University Medical Centre and ${ }^{\mathrm{h}}$ CARIM School for Cardiovascular Diseases, and MaCSBio Maastricht Centre for Systems Biology, Maastricht University, Maastricht, The Netherlands

Correspondence to Lieke E.J.M. Scheepers, MSc, Ing., Department of Rheumatology, Maastricht University Medical Centre+, Postbus 5800, 6202 AZ Maastricht, The Netherlands. Tel: +00316 18984522; fax: +0031 433 875006;

e-mail: lieke.scheepers@maastrichtuniversity.nl

Received 25 October 2016 Revised 2 December 2016 Accepted 30 December 2016 J Hypertens 35:982-993 Copyright (C) 2017 Wolters Kluwer Health, Inc. All rights reserved.

DOI:10.1097/HJH.0000000000001270 


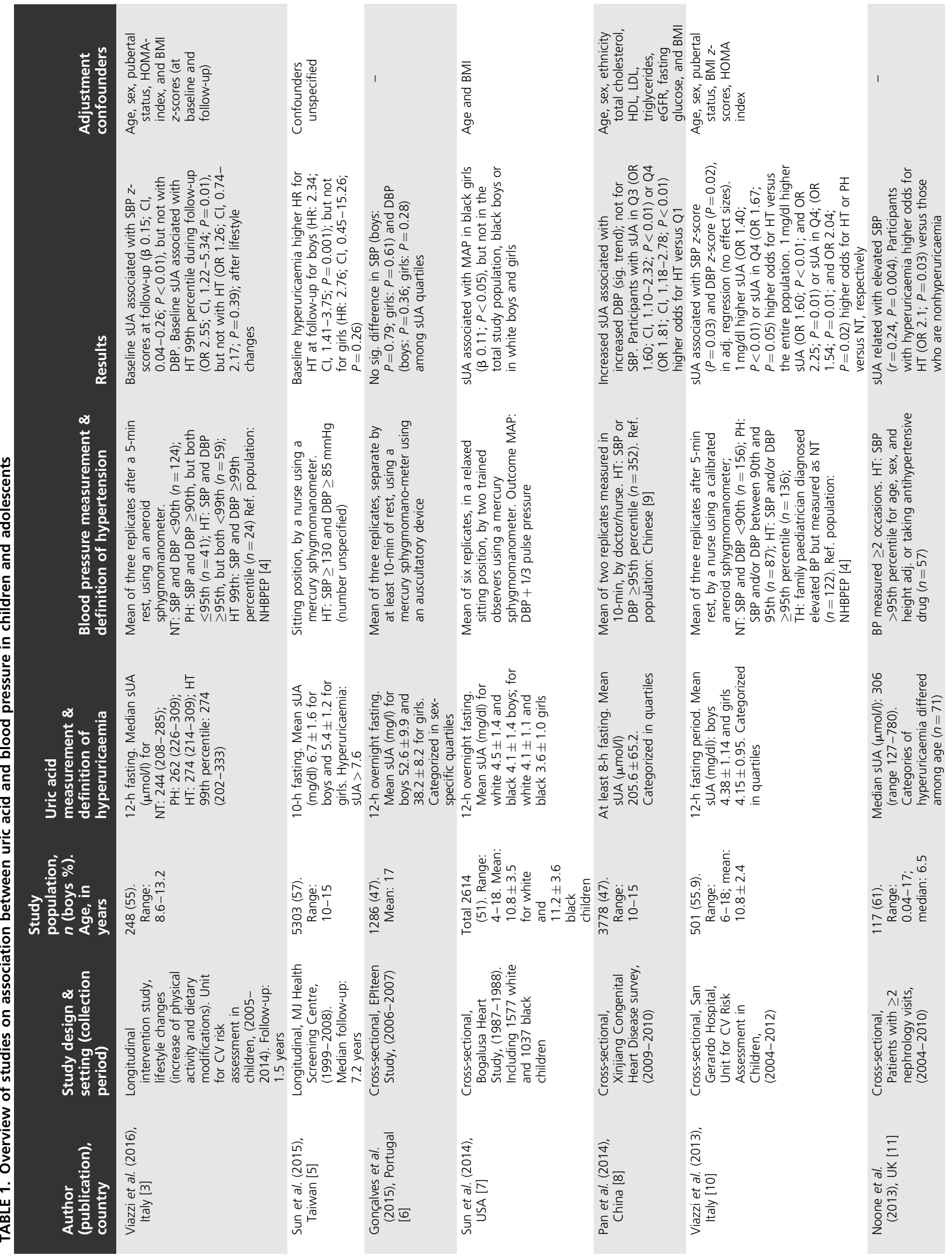




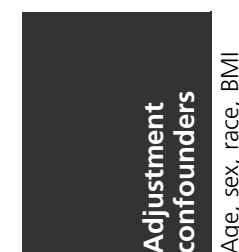

产

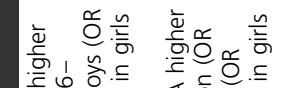
을

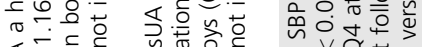

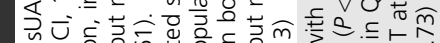
$\simeq \infty$.

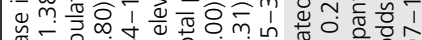

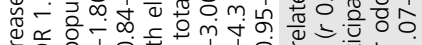

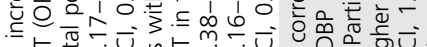


E.

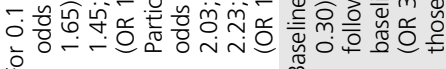

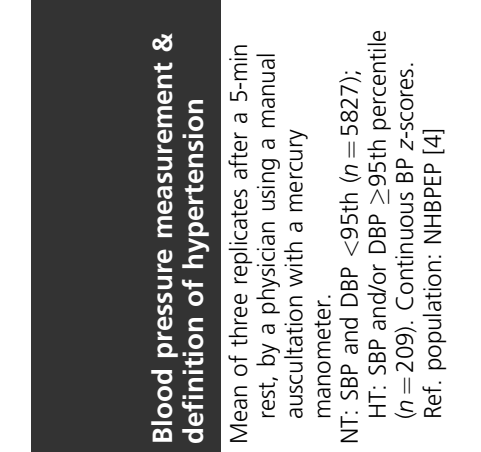

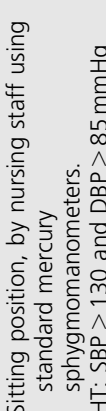


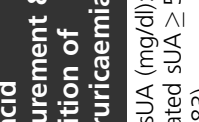







$\Sigma$

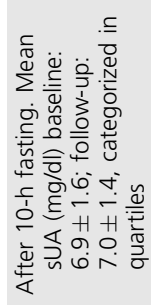

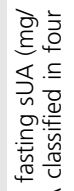



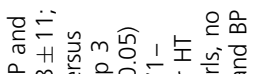

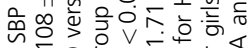

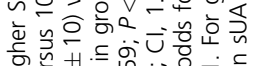

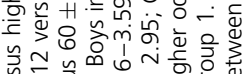

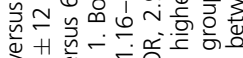

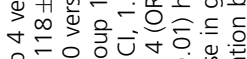

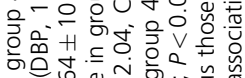

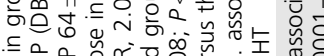



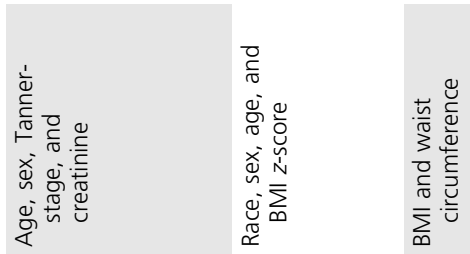

نे ชั่

응

ڤิํำ

?

उ

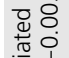
醇
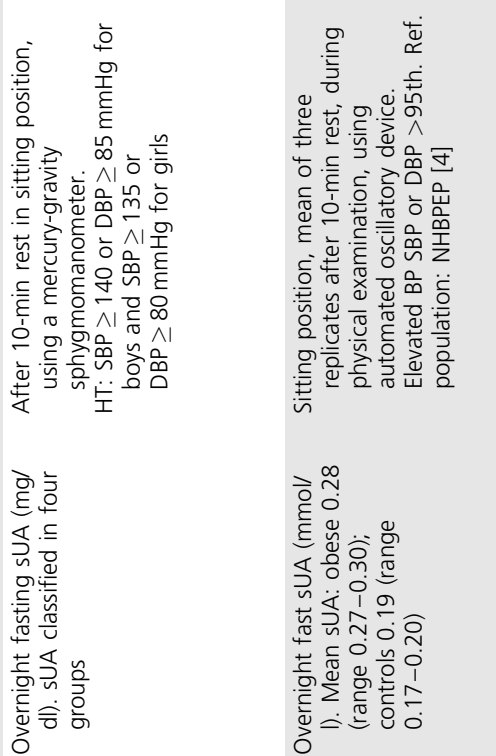

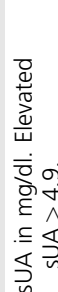

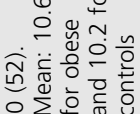


$\frac{m}{6}$



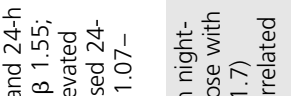

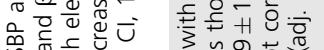

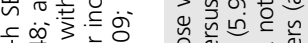

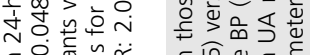



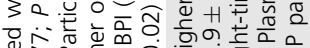

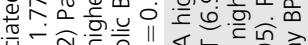

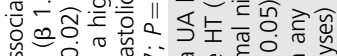

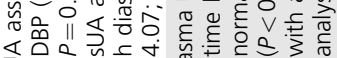

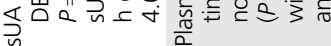

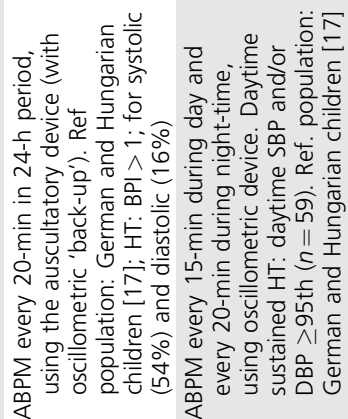

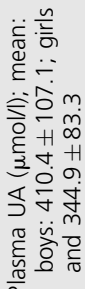




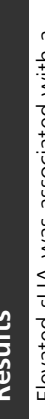

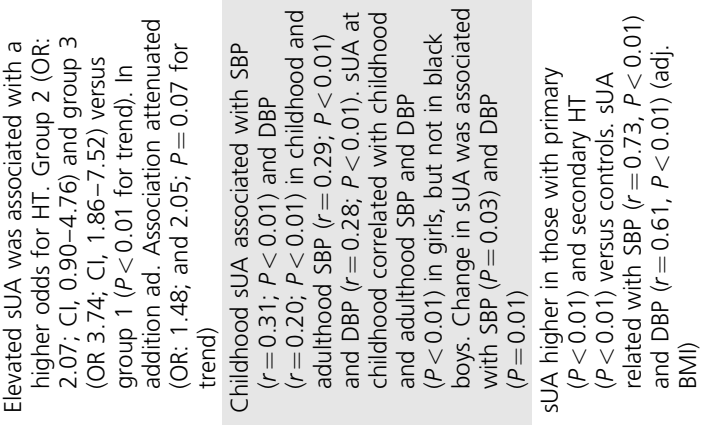

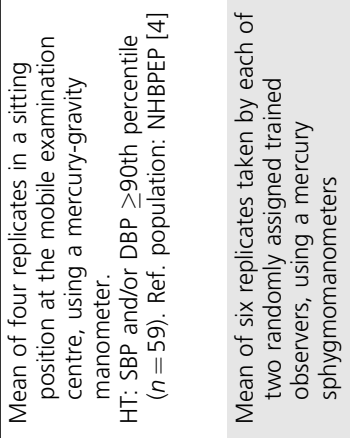

$\widehat{\mathrm{a}}$

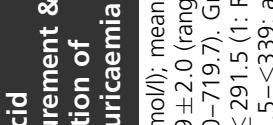



के $\rightarrow$ 垔 亮

范

$\sim T$

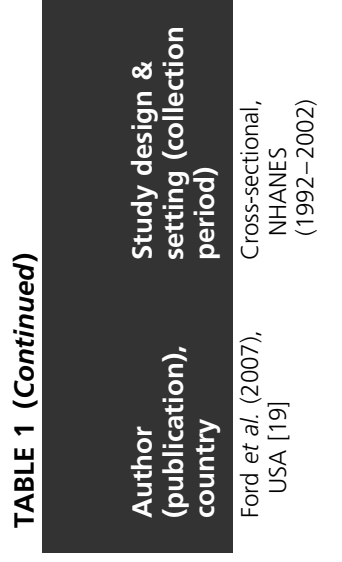




वृष्य

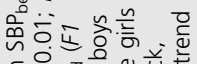

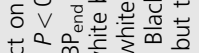

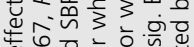

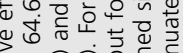





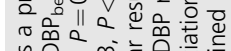

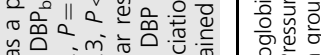

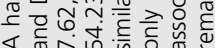
公 西

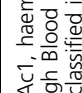





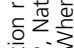





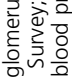



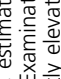

단단.

总芝

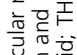

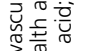





这瓷

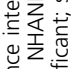

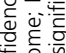



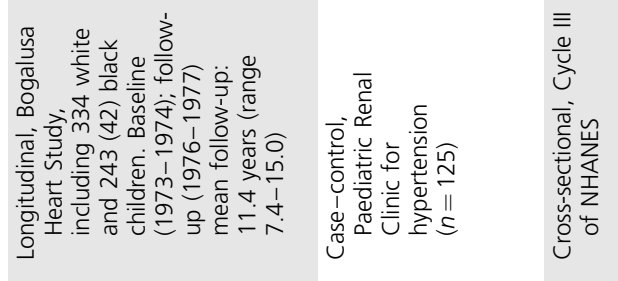

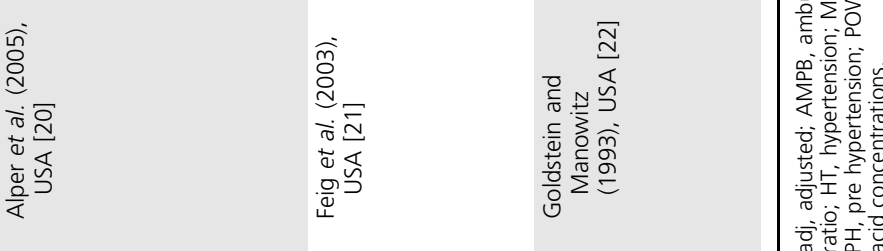




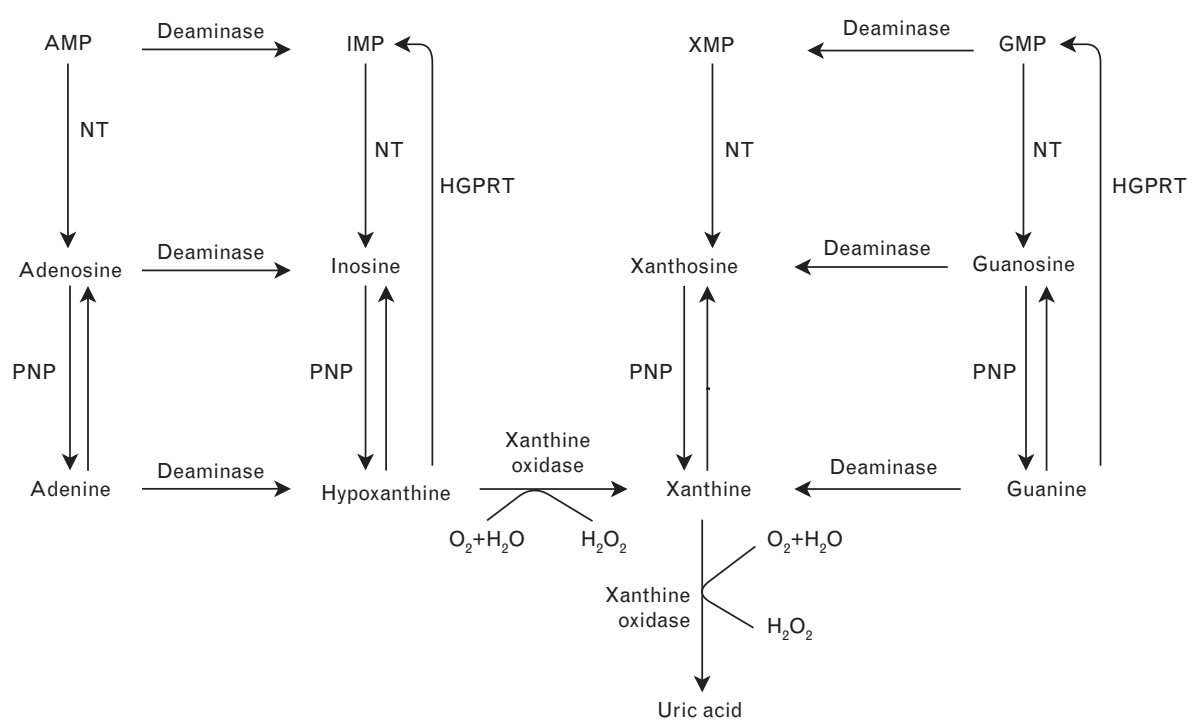

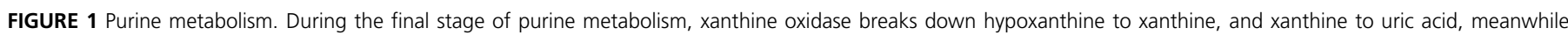

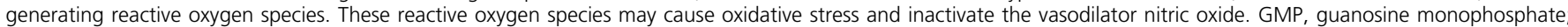

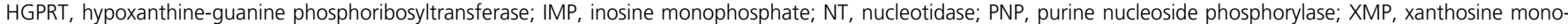
phosphate.

stimulates the renin-angiotensin system, leading to increased production of the vasoconstrictor angiotensin II [23]. Another mechanism not directly related to uric acid concentration, but rather to its production, is the generation of reactive oxygen species (ROS) during the production of uric acid. In the terminal steps of the purine catabolism, the rate-limiting enzyme xanthine oxidase (XO) catalyzes the oxidation of hypoxanthine to xanthine and xanthine to uric acid (Fig. 1). The main sources of $\mathrm{XO}$ are the liver [24-26] and intestine [27]; but XO can also be released into plasma and circulate to remote sites in which it binds to the surface of endothelial cells [28]. When molecular oxygen acts as the electron acceptor, superoxide radical anion $\left(\mathrm{O}_{2}{ }^{\bullet-}\right)$ [29], and hydrogen peroxide $\left(\mathrm{H}_{2} \mathrm{O}_{2}\right)$ are generated as by-products of the oxidation step. These ROS inhibit endothelial nitric oxide (NO) production and consequently impair the vasodilatory reaction $[28,30,31]$. In addition, the ROS produced by $\mathrm{XO}$ activity induce the adherence of leukocytes to endothelial cells, which in turn leads to more ROS generation and the initiation of proinflammatory events [28].

We hypothesize that uric acid production, independent of its concentration, contributes to elevated BP and hypertension. As uric acid concentration is not an adequate marker for the production, proxies for uric acid production need to be investigated (Fig. 2). As is known that $\mathrm{XO}$ is a rate-limiting enzyme, an increased $\mathrm{XO}$ activity may lead to a relative decrease in the more upstream metabolites, thus, lower hypoxanthine compared with xanthine and lower xanthine compared with uric acid concentration, resulting in higher ratios of xanthine/hypoxanthine, uric acid/ xanthine, and uric acid/hypoxanthine. The latter is based on animal studies and studies examining patients with xanthine oxidoreductase deficiency, a genetic disorder called xanthinuria, who have decreased concentrations of the more upstream metabolites [32-35].

In view of the above, the aims of the present study were to extend existing evidence on the relation between plasma uric acid concentration and BP to school-age children, and to investigate associations between purine metabolite ratios, considered as proxies for an increased XO activity, and BP. Younger individuals are a desirable population in which to investigate this relationship, as common hypertension and metabolic risk factors are less likely to be present. Furthermore, uric acid may be involved in the development of hypertension before vascular damage has occurred but may have less influence on BP levels once vascular damage is permanent [36].

\section{METHODS}

\section{Participants and study design}

The current analyses were conducted in the context of the KOALA Birth Cohort Study [Kind, Ouders en gezondheid: Aandacht voor Leefstijl en Aanleg (A Dutch acronym for child, parents and health: lifestyle and genetic constitution)] in the Netherlands [37]. In the years 2000-2002, pregnant women were recruited at 34 weeks of gestation and followed since. The cohort originates from two recruitment groups: healthy pregnant women with a conventional lifestyle $(n=2343)$ and pregnant women recruited through alternative channels $(n=491)$ (Fig. 2$)$. The women with a conventional lifestyle have been retrieved from an ongoing prospective cohort study on pregnancy-related pelvic girdle pain study in the Netherlands. The second recruitment group consists of pregnant women acquired through anthroposophic doctors and midwives, anthroposophic under-five clinics, posters in organic food shops, magazines for special interest groups, and Steiner schools. The latter group of women was considered to have an alternative lifestyle that could involve dietary habits (vegetarian, organic), child rearing practices, vaccination schemes, and/or use of antibiotics. All parents had signed the informed consent and the study was approved by the Medical Ethics Committee of Maastricht University Medical Centre+ (Maastricht UMC+). 


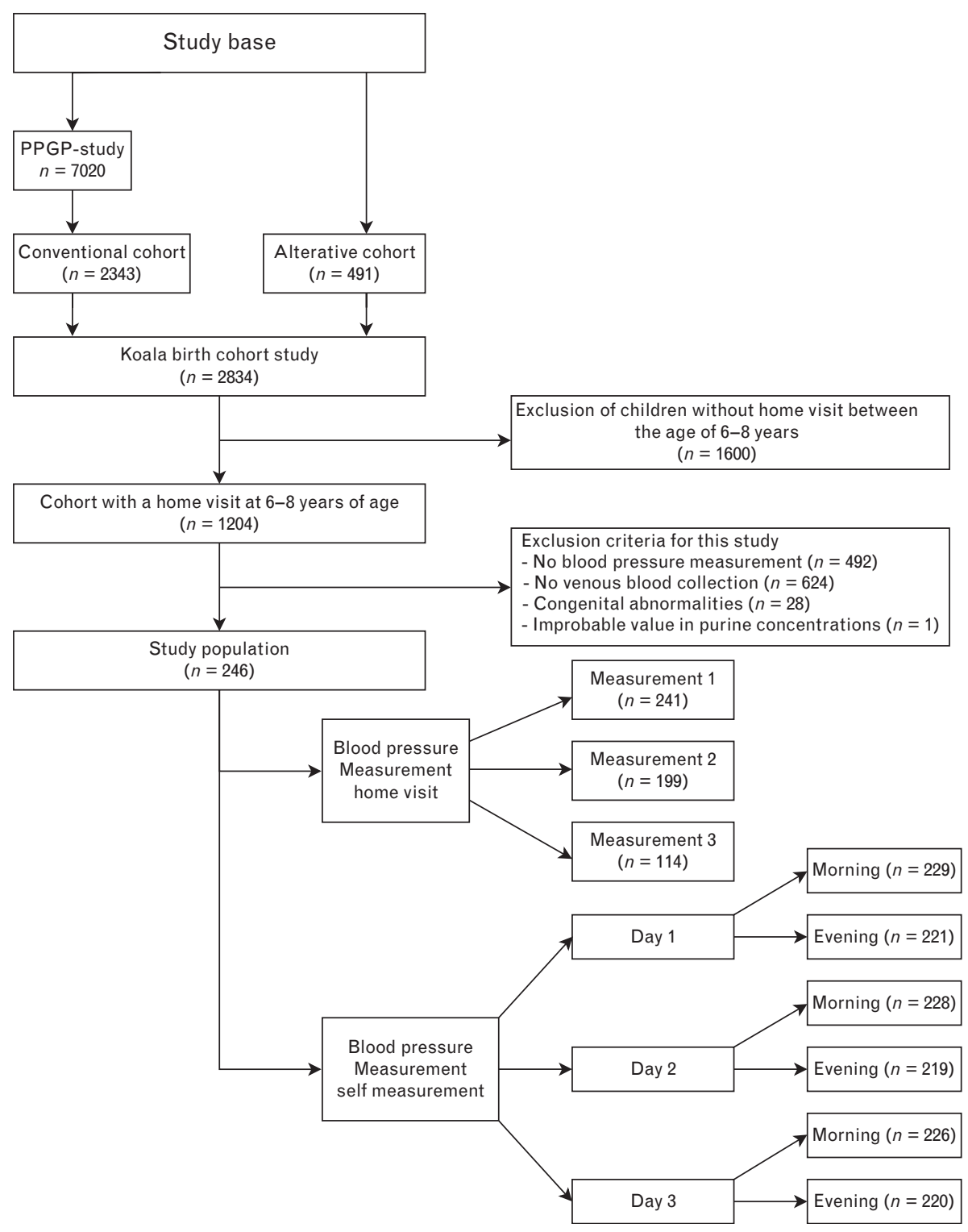

FIGURE 2 Flow chart of the study population. The KOALA Birth Cohort study included pregnant women with a conventional lifestyle (recruited from the on-going Pregnancy-related Pelvic Girdle Pain study) or those recruited through 'alternative' channels. Reasons for exclusion with numbers are presented.

A subgroup of 1204 parents was asked for consent for a home visit for anthropometric measurements, collection of venous blood, and a BP measurement from the child at the age of $6-7$ years. This subgroup comprised participants who had home visits for blood collection from the mother during pregnancy and/or the child at age 2 years, and who were still active participants. Venous blood samples were obtained from 600 children and BP measurements from 712 children. Exclusion criteria for the current study were children with congenital heart disease, severe mental disability and/or severe autism, twins, and improbable values in purine concentrations. A total of 246 children that met the criteria were included in the present study (Fig. 2).

Information on potential confounders was prospectively collected by parent-completed questionnaires during pregnancy (weeks 14 and 34) and at ages 3, 7, 12, and
24 months, $4-5$ years, and 6-7 years of the child. Dietary information was collected using a food frequency questionnaire (FFQ) covering a period of 4 weeks at the age of 4 years. The FFQ was specifically developed to assess childhood energy intake and validated by the doubly labelled water method [38]. Details on collection of dietary information are described elsewhere [39]. During the home visit at 6-7 years, the child's body weight and height were measured. BMI (weight/height ${ }^{2}, \mathrm{~kg} / \mathrm{m}^{2}$ ) was standardized by recoding it into age-specific and sex-specific BMI $z$-scores using data from the Dutch reference population [40]. For descriptive purposes, children were classified into normal weight (BMI $z$-score $<1.04$, corresponding to the 85th percentile), overweight (BMI $z$-score between $\geq 1.04$ and $<1.65$, corresponding to the 85 th and 95 th percentile), and obesity (BMI $z$-score between $\geq 1.65$, corresponding to the 95th percentile) [41]. 


\section{Purine metabolite determination}

Venous blood samples were collected in EDTA tubes during the home visit to assess uric acid, xanthine, and hypoxanthine concentrations in plasma. For ethical reasons children were not asked to fast overnight; however, $1.5 \mathrm{~h}$ prior to and during the home visit, the children were not allowed to eat or drink, resulting in a mean fast time of $2.2 \mathrm{~h}$ (SD $1.2 \mathrm{~h}$ ). After collection, the samples were stored at $-20{ }^{\circ} \mathrm{C}$ and thawed in a water bath at $37^{\circ} \mathrm{C}$ prior to analysis and homogenated by vortex mixing. A volume of $30 \mu \mathrm{l}$ plasma was mixed with $30 \mu$ l of internal standards solution, and while vortex mixing $500 \mu$ l of acetonitrile was added and vortex mixed for another $10 \mathrm{~s}$. After centrifugation, the supernatant was transferred to a glass sample vial and evaporated to dryness under nitrogen gas at $45^{\circ} \mathrm{C}$ for $\pm 15 \mathrm{~min}$. The sample was then taken up in $150 \mu \mathrm{l}$ $50 \mathrm{mmol} / 1$ ammoniumformiate $\mathrm{pH}$ 4.00. The purine metabolites were determined with ultra-performance liquid chromatography-tandem mass spectrometry [42]. The ratios of uric acid to xanthine [uric acid ( $\mu \mathrm{mol} / \mathrm{l}) / \mathrm{xanthine}$ $(\mu \mathrm{mol} / 1)$ ], uric acid to hypoxanthine [uric acid $(\mu \mathrm{mol} / 1) /$ hypoxanthine $(\mu \mathrm{mol} / \mathrm{l})]$, and xanthine to hypoxanthine [xanthine $(\mu \mathrm{mol} / 1) /$ hypoxanthine $(\mu \mathrm{mol} / 1)$ ] were calculated.

\section{Blood pressure measurement}

Mean arterial BP was measured during the home visit, using a validated Omron 705IT oscillometric automated BP monitor (Omron Healthcare Europe BV, Hoolddorp, the Netherlands) [43]. The device automatically provided an estimated SBP and DBP. Up to three measurements were performed by a trained nurse after a 5-min rest, whereas the child was sitting and not allowed to talk or move. BP was measured up to three times on the upper left arm while it was resting on a table. Afterwards, parents were asked to measure their child's BP on three consecutive days, in the morning and in the evening. The parents were instructed by the trained nurse and the same protocol was used. SBP and DBP percentiles and $z$-scores were calculated according to the nomograms recommended by the National High Blood Pressure Education Program on High Blood Pressure in Children and Adolescents (in the Fourth Report) [4]. As BP was measured with an oscillometric device during a single study visit, a formal diagnosis of hypertension is not possible. Therefore, participants were characterized as having 'normal blood pressure' if the mean (measurement performed by the nurse) of SBP and DBP were both less than 95th percentile and 'elevated blood pressure' if the mean SBP or DBP percentile was at least 95th percentile.

\section{Statistical analysis}

The characteristics of the participants are given as numbers and proportions for categorical variables and as mean (SD) or median (interquartile range) values for continuous variables with a normal or nonnormal distribution, respectively. Missing values were classified as unknown for categorical variables (maternal smoking during pregnancy $n=3$; passive smoking during pregnancy $n=6$ ). Participants with missing values on the FFQ $(n=11)$ were excluded for the analyses in the third model. Data analysis was performed using SPSS version 20.0 (SPSS Inc., Chicago, Illinois, USA).

Uric acid concentration differs between men and women; therefore, purine values and their ratios were compared between boys and girls with the independent $t$ test [44] or Mann-Whitney test for values with a normal or nonnormal distribution data, respectively. Standardized SBP and DBP $z$-scores were compared across the three different conditions (home visit measurements versus selfmeasurement and self-measurements in the morning versus self-measurements in the evening), using the dependent $t$ test, respectively.

Generalized estimating equation (GEE) models with unstructured correlation structure were used for analysis of the repeated BP measurements [studied as standardized $z$-scores (adj. for age, sex, and height $z$-scores)]. Up to nine measurements were available, taken under three different conditions. The BP measurement condition (as the index variable) and recruitment group (conventional; alternative) as confounder were included in the first model. The analyses included only one single purine metabolite or ratio at a time. In the second model, the following confounders were additionally included: age, infant sex (male, female), and BMI $z$-scores. In the third model, potential confounders that changed the regression coefficient of uric acid and SBP or DBP by more than 10\% were added to the GEE model. The following variables met this criterion: place and mode of delivery (vaginal delivery at home, vaginal delivery in hospital, artificial delivery in hospital, and caesarean section in hospital), maternal smoking during pregnancy (no, yes, and unknown), passive smoking during pregnancy ( $<1$ h a week, $>1$ h a week, and unknown), total physical activity at $4-5$ years of age (h/week), energy intake (kJ/day), protein intake (\%), carbohydrate intake (\%), and fibre intake (g/day). By adding dietary variables as confounder in the analyses, we attempt to control for dietary factors that potentially affect BP. The following variables did not meet the criterion and were therefore not included in the third model: prematurity (born before 37 weeks of gestation), maternal prepregnancy BMI $\left(\mathrm{kg} / \mathrm{m}^{2}\right)$, alcohol consumption during late pregnancy (number of consumptions), education level of the mother (lower education, middle education, and high education), birth weight (in grams), duration of breastfeeding (months), and fasting time before blood collection $(\mathrm{h})$.

Finally, we tested whether the association between uric acid concentrations with BP $z$-scores was modified by sex or BP measurement condition by including an interaction term in the fully adjusted GEE model. The interaction terms were nonsignificant $(P$ value $>0.05)$; therefore, the analyses were not stratified by sex or BP measurement condition.

\section{RESULTS}

The characteristics of the KOALA cohort $(n=2834)$ and the study population are shown in Table 2 . The study population consisted of 246 children, who were on average ages $7.1 \pm 0.4$ years and of whom 114 (46.3\%) were boys. In general, the two populations were similar, except that the study population consisted of less mothers who smoked 
TABLE 2. Baseline characteristics of the KOALA Birth Cohort Study and the study population

\begin{tabular}{|c|c|c|c|}
\hline & & $\begin{array}{l}\text { KOALA birth cohort study, } \\
\qquad n=2834\end{array}$ & $\begin{array}{l}\text { Study population, } \\
\qquad n=246\end{array}$ \\
\hline Sex, boy $[n(\%)]$ & & $1543(50.9)$ & $114(46.3)$ \\
\hline Recruitment group, conventional [ $n(\%)]$ & & $2343(82.7)$ & $207(84.1)$ \\
\hline Age during home visit (years) (mean $\pm S D$ ) & & - & $7.05 \pm 0.41$ \\
\hline BMl $z$-score during home visit (mean $\pm S D$ ) & & - & $-0.24 \pm 0.87$ \\
\hline Normal weight $[n(\%)]$ & & & $227(92.3)$ \\
\hline Overweight $[n(\%)]$ & & & $16(6.5)$ \\
\hline Obese $[n(\%)]$ & & & $3(1.2)$ \\
\hline Height $z$-scored (mean \pm SD) & & & $0.50 \pm 0.88$ \\
\hline Birth weight $(\mathrm{g})($ mean \pm SD) & & $3504 \pm 512$ & $3551 \pm 438$ \\
\hline \multirow[t]{4}{*}{ Maternal education ${ }^{a}[n(\%)]$} & Low & $289(9.5)$ & $20(8.1)$ \\
\hline & Middle & $1060(34.9)$ & $89(36.2)$ \\
\hline & High & $1341(44.2)$ & $123(50.0)$ \\
\hline & Unknown & $343(11.3)$ & $14(5.7)$ \\
\hline Maternal prepregnancy BMI (mean \pm SD) & & $23.5 \pm 4.5$ & $23.5 \pm 4.1$ \\
\hline \multirow[t]{2}{*}{ Maternal smoking during pregnancy $[n(\%)]$} & Yes & $222(7.3)$ & $11(4.5)$ \\
\hline & Unknown & 209 (6.9) & $3(1.2)$ \\
\hline \multirow{2}{*}{$\begin{array}{l}\text { Maternal passive smoking during pregnancy } \\
(>1 \mathrm{~h} \text { week) }[\mathrm{n}(\%)]\end{array}$} & Yes & $448(14.8)$ & $23(9.3)$ \\
\hline & Unknown & $255(8.4)$ & $6(2.4)$ \\
\hline $\begin{array}{l}\text { Alcohol consumption during pregnancy } \\
\text { (number of glasses) (mean } \pm \text { SD) }\end{array}$ & & $0.3 \pm 0.9$ & $0.2 \pm 0.7$ \\
\hline \multirow[t]{3}{*}{ Duration of pregnancy [n (\%)] } & Mean $\pm S D$ & $39.8 \pm 5.0$ & $39.5 \pm 1.1$ \\
\hline & $<37$ weeks & $93(3.1)$ & $0(0)$ \\
\hline & Unknown & $202(6.7)$ & $1(0.4)$ \\
\hline \multirow[t]{6}{*}{ Place and mode of delivery ${ }^{b}[n(\%)]$} & Natural delivery at home & $1187(39.1)$ & $113(45.9)$ \\
\hline & Natural delivery in hospital & $924(30.5)$ & $81(32.9)$ \\
\hline & Artificial delivery at home & $1(0.0)$ & $0(0.0)$ \\
\hline & Artificial delivery in hospital & $223(7.4)$ & $23(9.3)$ \\
\hline & Caesarean section in hospital & $311(10.3)$ & $28(11.4)$ \\
\hline & Unknown & $381(12.6)$ & $1(0.4)$ \\
\hline $\begin{array}{l}\text { Duration of breastfeeding (months) } \\
\quad(\text { mean } \pm \mathrm{SD})\end{array}$ & & $4.91 \pm 4.55$ & $5.5 \pm 4.2$ \\
\hline Total physical activity (h/week) (mean \pm SD) & & $9.4 \pm 4.5$ & $9.6 \pm 4.7$ \\
\hline \multirow{5}{*}{$\begin{array}{l}\text { Dietary factors of the child at age four } \\
\quad(\text { mean } \pm \text { SD })^{c}\end{array}$} & Total energy intake (kJ) & $6172 \pm 1286$ & $6086 \pm 1331$ \\
\hline & Energy percentage from fat & $29.6 \pm 4.2$ & $29.6 \pm 3.9$ \\
\hline & Energy percentage from protein & $14.6 \pm 2.1$ & $14.8 \pm 2.1$ \\
\hline & $\begin{array}{l}\text { Energy percentage from } \\
\text { carbohydrate }\end{array}$ & $55.8 \pm 5.0$ & $55.5 \pm 4.7$ \\
\hline & Fibre (g) & $2.5 \pm 0.5$ & $2.5 \pm 0.5$ \\
\hline
\end{tabular}

Numbers do not always add up to the total because of missing data.

aLow: primary school, preparatory vocational or lower general secondary school, middle: vocational, higher general secondary or preuniversity education, high: higher vocational or

academic education.
${ }^{b}$ Artificial delivery: induced labour, as when started with drugs or medical devices.

'Missing data for 13 participants on variables total physical activity and dietary factors.

during pregnancy (active and passive) and more children were delivered naturally at home than in the entire KOALA cohort.

Data on purine metabolite concentrations and their ratios are shown in Table 3 . The mean plasma uric acid concentration was slightly higher for boys [203.9 $\mu \mathrm{mol} / 1$ (SD 39.6)] than for girls [201.8 $\mu \mathrm{mol} / 1$ (SD 36.2)] but did not differ significantly $(P=0.67)$. Median hypoxanthine [boys: $2.4 \mu \mathrm{mol} / 1$ (IQR 2.7); girls $2.5 \mu \mathrm{mol} / \mathrm{l}$ (IQR 3.5)] and mean xanthine concentrations [boys: $0.5 \mu \mathrm{mol} / 1$ (SD 0.20); girls:

TABLE 3. Plasma concentrations of uric acid, xanthine, and hypoxanthine and their ratios

\begin{tabular}{|c|c|c|c|c|}
\hline & & Total population, $n=246$ & Boys, $n=114$ & Girls, $n=132$ \\
\hline \multicolumn{5}{|l|}{ Purine metabolite } \\
\hline Uric acid $(\mu \mathrm{mol} / /)$ & Mean $\pm S D$ & $202.8 \pm 37.7$ & $203.9 \pm 39.6$ & $201.8 \pm 36.2$ \\
\hline Xanthine $(\mu \mathrm{mol} / \mathrm{l})$ & Mean $\pm S D$ & $0.53 \pm 0.17$ & $0.53 \pm 0.20$ & $0.53 \pm 0.15$ \\
\hline Hypoxanthine $(\mu \mathrm{mol} / \mathrm{l})$ & Median (IQR) & $2.5(3.2)$ & $2.4(2.7)$ & $2.5(3.5)$ \\
\hline \multicolumn{5}{|l|}{ Ratio } \\
\hline Uric acid/xanthine & Mean \pm SD & $417.2 \pm 138.4$ & $425.0 \pm 154.1$ & $410.5 \pm 123.4$ \\
\hline Uric acid/hypoxanthine & Median (IQR) & $83.9(94.5)$ & $86.7(102.5)$ & $81.6(86.5)$ \\
\hline Xanthine/hypoxanthine & Median (IQR) & $4.7(4.8)$ & $4.7(4.6)$ & $4.6(4.8)$ \\
\hline
\end{tabular}

$\mathrm{IQR}$, interquartile range. 
TABLE 4. Blood pressure levels measured by a trained nurse during the home visit and by the parents in the morning and evening

\begin{tabular}{|c|c|c|c|}
\hline & & SBP Z-scores & DBP z-scores \\
\hline \multicolumn{4}{|l|}{ Home visit ${ }^{a}$} \\
\hline & Mean \pm SD & $0.84 \pm 0.69$ & $0.49 \pm 0.86$ \\
\hline \multicolumn{4}{|c|}{ Self-measurement } \\
\hline Morning ${ }^{b}$ & Mean \pm SD & $0.78 \pm 0.94$ & $0.49 \pm 0.88$ \\
\hline Evening $^{c}$ & Mean \pm SD & $0.88 \pm 0.94$ & $0.49 \pm 0.85$ \\
\hline
\end{tabular}

BP, blood pressure. ${ }^{a}$ Home visit: BP is measured by a trained nurse, the mean of three replicates. Self-measurement: BP is measured by the parents on three consecutive days, in the ${ }^{\mathrm{b}}$ morning and ${ }^{\mathrm{c} e v e n i n g}$. Missing for each condition: home visit: $n=5$ (boys $n=1$; girls $n=4$; self-measurement: morning $n=16$ (boys $n=5$; girls $n=11$ ) and evening $n=23$ (boys $n=8$; girls $n=15$ ).

$0.5 \mu \mathrm{mol} / \mathrm{l}$ (SD 0.15)] and the different ratios did not differ substantially by sex.

In Table 4, BP data are presented. Elevated BP was found in $64(26 \%)$ of the children. The correlation among the selfmeasurement ranged from 0.20 up to 0.50 . BP $z$-scores were higher when measurements were performed by the parents than these performed by the nurse $(P$ value $<0.001)$. Furthermore, measurements performed in the evening were higher than these performed in the morning for SBP $z$-score $(P=0.001)$, but not for DBP $z$-score $(P=0.96)$.

\section{Purine metabolite concentrations and blood pressure}

Multivariable analysis showed that a 1 SD $(38 \mu \mathrm{mol} / 1)$ higher plasma uric acid concentration was associated with a higher DBP $z$-scores, although statistical significance was only reached in the fully adjusted model [adj. s $\beta \quad 0.07 ; 95 \%$ confidence interval (CI), 0.01-0.14 mmHg]. No association was found with SBP $z$-scores (Table 5). Plasma xanthine and hypoxanthine concentrations were not associated with SBP $z$-scores or DBP $z$-scores, regardless of adjustment for potential confounders. Although the association between plasma hypoxanthine with DBP $z$-scores was close to significance (adj. s $\beta$ 0.06; CI, -0.01 to $0.13 ; P=0.10$ ). An increase of 0.10 DBP $z$-score represents a difference of $0.93 \mathrm{mmHg}$ for a 6-year-old boy with a height $z$-score of 0.00 .

\section{Purine metabolite ratios and blood pressure}

The ratios uric acid/xanthine and xanthine/hypoxanthine were associated with DBP $z$-scores, although statistical significance was only reached in the fully adjusted model (adj. s $\beta$ 0.09; CI, 0.01-0.17) and (adj. s $\beta$ 0.08; CI, 0.02$0.14)$, respectively. None of the ratios was significantly associated with SBP $z$-scores. The ratio uric acid/hypoxanthine was associated with DBP $z$-scores in the crude model but lost significance after adjustment for potential confounders.

\section{DISCUSSION}

The present study showed that, in school-age children, elevated plasma uric acid concentration was associated with higher DBP $z$-scores. Furthermore, elevated ratios of uric acid/xanthine and xanthine/hypoxanthine, considered as proxies for increased XO activity, were associated with higher DBP $z$-scores. Our findings support the hypothesis that next to an elevated uric acid concentration, an increased $\mathrm{XO}$ activity is associated with elevated BP.

Although an association between serum uric acid concentration and BP has been described before in older children and adolescents (summarized in Table 1), we were the first to show an association in school-age children at a mean age of 7 years. The studies performed so far mainly studied older children (with a mean age of 10 years or higher) and adolescents [7,10,16,20,21]. Moreover, we found an effect in a relatively healthy group of children, with respect to both the participants' uric acid concentration [hyperuricaemia (plasma uric acid concentration $>5.0 \mathrm{mg} / \mathrm{dl}$ ) $n=0$ ], whereas other studies often investigate

\begin{tabular}{|c|c|c|c|c|c|c|c|}
\hline & & Model $1 \mathrm{~s} \beta(95 \% \mathrm{Cl})^{a}$ & $P$ & Model 2 s $\beta(95 \% \mathrm{Cl})^{b}$ & $P$ & Model 3 s $\beta(95 \% \mathrm{CI})^{c}$ & $P$ \\
\hline \multicolumn{8}{|l|}{ Purine metabolite } \\
\hline \multirow[t]{2}{*}{ Uric acid } & SBP & $0.000(-0.08$ to 0.07$)$ & 0.99 & $0.01(-0.07$ to 0.08$)$ & 0.90 & $-0.02(-0.10$ to 0.06$)$ & 0.70 \\
\hline & DBP & $0.04(-0.02$ to 0.11$)$ & 0.17 & $0.05(-0.01$ to 0.12$)$ & 0.08 & $0.07(0.01$ to 1.14$)$ & 0.03 \\
\hline \multirow[t]{2}{*}{ Xanthine } & SBP & $-0.001(-0.08$ to 0.08$)$ & 0.99 & $0.002(-0.08$ to 0.08$)$ & 0.97 & $-0.03(-0.10$ to 0.05$)$ & 0.49 \\
\hline & DBP & $-0.03(-0.10$ to 0.05$)$ & 0.61 & $-0.02(-0.10$ to 0.05$)$ & 0.54 & $-0.04(-1.11$ to 0.04$)$ & 0.35 \\
\hline \multirow[t]{2}{*}{ Hypoxanthine } & SBP & $0.01(-0.01$ to 0.10$)$ & 0.76 & $0.01(-0.07$ to 0.09$)$ & 0.78 & $0.01(-0.08$ to 0.10$)$ & 0.82 \\
\hline & DBP & $0.05(-0.02$ to 0.12$)$ & 0.13 & $0.06(-0.01$ to 0.12$)$ & 0.11 & $0.06(-0.01$ to 0.13$)$ & 0.10 \\
\hline \multicolumn{8}{|l|}{ Ratio } \\
\hline \multirow[t]{2}{*}{ Uric acid/xanthine } & SBP & $-0.01(-0.10$ to 0.08$)$ & 0.81 & $-0.01(-0.09$ to 0.05$)$ & 0.83 & $0.003(-0.08$ to 0.08$)$ & 0.93 \\
\hline & DBP & $0.06(-0.02$ to 0.14$)$ & 0.15 & $0.07(-0.01$ to 0.15$)$ & 0.10 & 0.09 (0.01 to 0.17$)$ & 0.03 \\
\hline \multirow[t]{2}{*}{ Uric acid/hypoxanthine } & SBP & $-0.002(-0.04$ to 0.04$)$ & 0.93 & $-0.01(-0.05$ to 0.04$)$ & 0.28 & $-0.003(-0.06$ to 0.06$)$ & 0.91 \\
\hline & DBP & $-0.03(-0.05$ to -0.00$)$ & 0.04 & $-0.03(-0.06$ to 0.01$)$ & 0.11 & $-0.03(-0.08$ to 0.01$)$ & 0.17 \\
\hline \multirow[t]{2}{*}{ Xanthine/hypoxanthine } & SBP & $0.01(-0.07$ to 0.10$)$ & 0.74 & $0.01(-0.07$ to 0.09$)$ & 0.79 & $0.03(-0.06$ to 0.12$)$ & 0.50 \\
\hline & DBP & $0.06(-0.00$ to 0.12$)$ & 0.06 & $0.06(-0.00$ to 0.12$)$ & 0.06 & $0.08(0.02$ to 0.14$)$ & 0.01 \\
\hline
\end{tabular}


uric acid/hypoxanthine 321.4, and xanthine / hypoxanthine 8.8). Outcome presented as standardized blood pressure $z$-scores (adj. for age, sex, and height $z$-scores; ref. population: NHBPEP [24]).

${ }^{a}$ Adjusted for recruitment group (conventional; alternative).

bIn addition, adjusted for age, sex, and BMI z-scores.

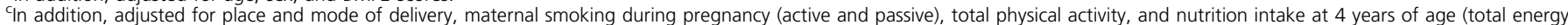

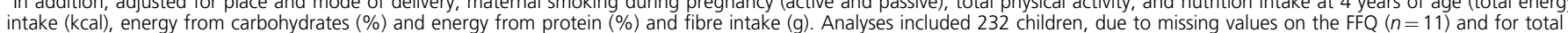
intake (kcal), energy from
physical activity $(n=13)$. 
children from clinical cohorts, who have a relatively high risk of cardiovascular diseases [3,11,15,16,18,21].

To the best of our knowledge, we were the first to study the association between $\mathrm{BP}$ and several ratios of purine metabolites as proxies for an increased XO activity in the vasculature. We showed that higher uric acid/xanthine and xanthine/hypoxanthine ratios were associated with higher DBP $z$-scores. Our hypothesis is based on studies examining the effect of a deficiency in XO on purine metabolite concentrations [33-35]; however, whether an opposite effect in purine metabolite concentrations occurs by an increased XO activity is unknown. Further investigation is required to examine whether increased $\mathrm{XO}$ activity leads to a relative increase in the more downstream metabolites and that this will not be compensated by alterations in urinary excretion of uric acid or xanthine, or the degradation of hypoxanthine to inosine monophosphate by hypoxanthine-guanine phosphoribosyltransferase [35].

In the present study, we found an association with DBP $z$-scores but not with SBP $z$-scores. Diastolic pressure and mean arterial pressure, the steady components of $\mathrm{BP}$, reflect peripheral vascular resistance. Particularly in younger individuals $(<50$ years of age), DBP is the main predictor of cardiovascular risk. Later in life SBP and pulse pressure, the pulsatile components of $\mathrm{BP}$ become the main predictors [45-47]. As previously described, there are several plausible mechanisms linking uric acid to vascular resistance [23]. For example, uric acid in the circulation activates angiotensin II, thereby stimulating the nicotinamide adenine dinucleotide (phosphate) (reduced form) (NAD $(\mathrm{P}) \mathrm{H})$ oxidase that is the main source of ROS in the vasculature. ROS reduces the bioavailability of vasodilator NO, leading to vascular resistance. In turn, ROS increases the formation of peroxynitrite, which can increase endothelial NO synthase uncoupling resulting in even more ROS formation [48,49]. Moreover, Landmesser et al. [50] found that angiotensin II substantially increases endothelial XO activation in cultured endothelial cells, subsequent to $\mathrm{NAD}(\mathrm{P}) \mathrm{H}$ oxidase activation, leading to even more ROS formation. Moreover, another mechanism not directly related to uric acid concentration, but rather to its production, is the accumulation of ROS during the degradation of purines by increased $\mathrm{XO}$ activity.

The magnitude of the BP change found in our study is relatively small; an increase of $1 \mathrm{SD}$ in uric acid concentration or uric acid/xanthine and xanthine/hypoxanthine ratios was associated with an increase of approximately 0.08 higher DBP $z$-score. This represents an increase in DBP by 2 percentiles (or $1 \mathrm{mg} / \mathrm{dl}$ increase in plasma uric acid leads to an increase in DBP by 3 percentiles). This is probably not clinically relevant during childhood, nevertheless when maintained during adolescence and adulthood, it can have clinical implications [3,20,21,51,52]. Prolonged exposure to increased peripheral vascular resistance and high BP leads to embedding of the vessel structure in a remodelled extracellular matrix [53,54]. Initially, the remodelling of arteries will be adaptive, but it eventually becomes maladaptive and increases stiffness, contributing to cardiovascular complications of hypertension [53]. Furthermore, an increase in uric acid concentration or $\mathrm{XO}$ activity may not have clinical implication at the time, but it increases the risk of hypertension later in life
[3,5,13,20]. For example, Viazzi et al. [3] showed, among children at high cardiovascular risk, that even a moderately increased serum uric acid concentration at baseline was associated with elevated BP after a mean follow-up of 1.5 years, regardless of appropriate lifestyle changes such as weight loss and diet. Accordingly, among participants in the Bogalusa Heart Study higher childhood serum uric concentration, even within the normal range, was associated with childhood and adult elevated BP (mean follow-up 11.4-year) [20].

In the current study, $\mathrm{BP} z$-scores were higher than these from the reference population (Table 4). We made use of an oscillometric device to measure BP, whereas the available reference values have been obtained by an auscultatory device. Values obtained by an oscillometric device are considerably higher than these obtained by an auscultatory device. In addition, the average BP measured by the parents was higher than that measured by the trained nurse during the home visits, regardless of time of measurement (morning or evening). This same phenomenon has been observed previously in young adolescents and adults $(<50$ years) [55], but in young children it has not been studied extensively $[56,57]$. Our results show that these differences already occur in early childhood.

Our study has both strengths and weaknesses that deserve to be commented on. The adjustment for potential confounders, quantification of several purine metabolites, and the repeated BP measurements are major strengths of our study. However, the present study must be interpreted within the context of its potential limitations. First, we would like to emphasize the need for studies examining whether an increased XO activity causes shifts in several purine metabolite concentrations and their ratios. Second, we used a cross-sectional design, so no conclusions concerning causality can be drawn. Third, an oscillometric device was used to measure mean arterial BP, and SBP and DBP were subsequently estimated. Reference data on oscillometric BP measurements would have been more appropriate to create SBP and DBP $z$-scores. Unfortunately, referential data on oscillometric BP measurements are limited and insufficiently validated. Further studies are required before a complete substitution can be made from using conventional auscultation method to oscillometry. Last, blood samples to determine the purine metabolites were only collected once. As purine concentrations can vary during the day, multiple measures would have been more accurate.

In conclusion, this study showed that plasma uric acid concentration and the ratios uric acid/xanthine and xanthine/hypoxanthine are associated with DBP $z$-scores in school-age children. These findings support the role of uric acid as a determinant of $\mathrm{BP}$, already in early childhood, and confirm our hypothesis that an increased XO activity, reflected by increased purine ratios, is associated with $\mathrm{BP}$. These findings highlight the need for further investigation on increased $\mathrm{XO}$ activity and $\mathrm{BP}$.

\section{AGKNOWLEDGEMENTS}

\section{Conflicts of interest}

There are no conflicts of interest. 


\section{REFERENCES}

1. Wang J, Qin T, Chen J, Li Y, Wang L, Huang H, Li J. Hyperuricemia and risk of incident hypertension: a systematic review and meta-analysis of observational studies. PLoS One 2014; 9:e114259.

2. Grayson PC, Kim SY, LaValley M, Choi HK. Hyperuricemia and incident hypertension: a systematic review and meta-analysis. Arthritis Care Res (Hoboken) 2011; 63:102-110

3. Viazzi F, Rebora P, Giussani M, Orlando A, Stella A, Antolini L, et al. Increased serum uric acid levels blunt the antihypertensive efficacy of lifestyle modifications in children at cardiovascular risk. Hypertension 2016; 67:934-940.

4. National High Blood Pressure Education Program Working Group on High Blood Pressure in Children and Adolescents. The fourth report on the diagnosis, evaluation, and treatment of high blood pressure in children and adolescents. Pediatrics 2004; 114 (2 Suppl 4th Report): $555-576$.

5. Sun HL, Pei D, Lue KH, Chen YL. Uric acid levels can predict metabolic syndrome and hypertension in adolescents: a 10-Year Longitudinal Study. PLoS One 2015; 10:e0143786.

6. Goncalves JP, Ramos E, Severo M, Wong MC, Ong KK, Dunger DB, Lopes C. Serum uric acid and cardiovascular risk among Portuguese adolescents. J Adolesc Health 2015; 56:376-381.

7. Sun D, Li S, Zhang X, Fernandez C, Chen W, Srinivasan SR, Berenson GS. Uric acid is associated with metabolic syndrome in children and adults in a community: the Bogalusa Heart Study. PLoS One 2014, 9:e89696.

8. Pan S, He CH, Ma YT, Yang YN, Ma X, Fu ZY, et al. Serum uric acid levels are associated with high blood pressure in Chinese children and adolescents aged 10-15 years. J Hypertens 2014; 32:998-1004.

9. Subspecialty Group of Endocrinologic, Hereditary and Metabolic Diseases, The Society of Pediatrics, Chinese Medical Association, Subspecialty Group of Cardiology, The Society of Pediatrics, Chinese Medical Association, Subspecialty Groups of Child Health Care, The Society of Pediatrics, Chinese Medical Association. The definition of metabolic syndrome and prophylaxis and treatment proposal in Chinese children and adolescents. Zhonghua Er Ke Za Zhi 2012 50:420-422.

10. Viazzi F, Antolini L, Giussani M, Brambilla P, Galbiati S, Mastriani S, et al. Serum uric acid and blood pressure in children at cardiovascular risk. Pediatrics 2013; 132:e93-e99.

11. Noone DG, Marks SD. Hyperuricemia is associated with hypertension, obesity, and albuminuria in children with chronic kidney disease J Pediatr 2013; 162:128-132.

12. Loeffler LF, Navas-Acien A, Brady TM, Miller ER 3rd, Fadrowski JJ. Uric acid level and elevated blood pressure in US adolescents National Health and Nutrition Examination Survey, 1999-2006. Hypertension 2012; 59:811-817.

13. Wang JY, Chen YL, Hsu CH, Tang SH, Wu CZ, Pei D. Predictive value of serum uric acid levels for the diagnosis of metabolic syndrome in adolescents. J Pediatr 2012; 161:753-760.

14. Hongo M, Hidaka H, Sakaguchi S, Nakanishi K, Ichikawa M, Hirota N, et al. Association between serum uric acid levels and cardiometabolic risk factors among Japanese junior high school students. Circ J 2010 74:1570-1577.

15. Pacifico L, Cantisani V, Anania C, Bonaiuto E, Martino F, Pascone R, Chiesa C. Serum uric acid and its association with metabolic syndrome and carotid atherosclerosis in obese children. Eur J Endocrinol 2009; $160: 45-52$.

16. Jones DP, Richey PA, Alpert BS, Li R. Serum uric acid and ambulatory blood pressure in children with primary hypertension. Pediatr Res 2008; 64:556-561.

17. Soergel M, Kirschstein M, Busch C, Danne T, Gellermann J, Holl R, et al Oscillometric twenty-four-hour ambulatory blood pressure values in healthy children and adolescents: a multicenter trial including 1141 subjects. J Pediatr 1997; 130:178-184.

18. Gilardini L, Parati G, Sartorio A, Mazzilli G, Pontiggia B, Invitti C. Sympathoadrenergic and metabolic factors are involved in ambulatory blood pressure rise in childhood obesity. J Hum Hypertens 2008; 22:75-82.

19. Ford ES, Li C, Cook S, Choi HK. Serum concentrations of uric acid and the metabolic syndrome among US children and adolescents. Circulation 2007; 115:2526-2532.
20. Alper AB Jr, Chen W, Yau L, Srinivasan SR, Berenson GS, Hamm LL. Childhood uric acid predicts adult blood pressure: the Bogalusa Heart Study. Hypertension 2005; 45:34-38.

21. Feig DI, Johnson RJ. Hyperuricemia in childhood primary hypertension. Hypertension 2003; 42:247-252.

22. Goldstein HS, Manowitz P. Relation between serum uric-acid and blood-pressure in adolescents. Ann Human Biol 1993; 20:423-431.

23. Yu MA, Sánchez-Lozada LG, Johnson RJ, Kang DH. Oxidative stress with an activation of the renin-angiotensin system in human vascular endothelial cells as a novel mechanism of uric acid-induced endothelial dysfunction. J Hypertens 2010; 28:1234-1242.

24. Della Corte E, Gozzetti G, Novello F, Stirpe F. Properties of the xanthine oxidase from human liver. Biochim Biophys Acta 1969; 191:164-166.

25. Guerciolini R, Szumlanski C, Weinshilboum RM. Human liver xanthine oxidase: nature and extent of individual variation. Clin Pharm Ther 1991; 50:663-672.

26. Stirpe F, Ravaioli M, Battelli MG, Musiani S, Grazi GL. Xanthine oxidoreductase activity in human liver disease. Am J Gastroenterol 2002; 97:2079-2085.

27. Auscher C, Amory N, van der Kemp P, Delbarre F. Xanthine oxidase activity in human intestines. Histochemical and radiochemical study. Adv Exp Med Biol 1979; 122B:197-201.

28. Houston M, Estevez A, Chumley P, Aslan M, Marklund S, Parks DA, Freeman BA. Binding of xanthine oxidase to vascular endothelium. Kinetic characterization and oxidative impairment of nitric oxidedependent signaling. J Biol Chem 1999; 274:4985-4994.

29. McCord JM, Fridovich I. The reduction of cytochrome c by milk xanthine oxidase. J Biol Chem 1968; 243:5753-5760.

30. Battelli MG, Bolognesi A, Polito L. Pathophysiology of circulating xanthine oxidoreductase: new emerging roles for a multitasking enzyme. Biochim Biophys Acta 2014; 1842:1502-1517.

31. So A, Thorens B. Uric acid transport and disease. J Clin Invest 2010; 120:1791-1799.

32. Lim SS, Vos T, Flaxman AD, Danaei G, Shibuya K, Adair-Rohani H, et al A comparative risk assessment of burden of disease and injury attributable to 67 risk factors and risk factor clusters in 21 regions, 1990-2010: a systematic analysis for the Global Burden of Disease Study 2010. Lancet 2012; 380:2224-2260.

33. Tanaka K, Kanazawa I, Yamasaki H, Hasegawa H, Ichida K, Sugimoto T. Xanthinuria type I with a novel mutation of xanthine dehydrogenase. Am J Med Sci 2015; 350:155-156.

34. Zhou YN, Zhang X, Ding R, Li Z, Hong Q, Wang Y, et al. Using nextgeneration sequencing to identify a mutation in human MCSU that is responsible for type II xanthinuria. Cell Physiol Biochem 2015; 35:2412-2421.

35. Curto R, Voit EO, Sorribas A, Cascante M. Mathematical models of purine metabolism in man. Math Biosci 1998; 151:1-49.

36. Feig DI. The role of uric acid in the pathogenesis of hypertension in the young. J Clin Hypertens (Greenwich) 2012; 14:346-352.

37. Kummeling I, Thijs C, Penders J, Snijders BE, Stelma F, Reimerink J, et al. Etiology of atopy in infancy: the KOALA Birth Cohort Study. Pediatr Allergy Immunol 2005; 16:679-684.

38. Dutman AE, Stafleu A, Kruizinga A, Brants HA, Westerterp KR, Kistemaker $\mathrm{C}$, et al. Validation of an FFQ and options for data processing using the doubly labelled water method in children. Public Health Nutr 2011; 14:410-417.

39. Scheepers LE, Penders J, Mbakwa CA, Thijs C, Mommers M, Arts IC. The intestinal microbiota composition and weight development in children: the KOALA Birth Cohort Study. Int J Obes (Lond) 2015; 39:16-25.

40. Fredriks AM, van Buuren S, Wit JM, Verloove-Vanhorick SP. Body index measurements in 1996-7 compared with 1980. Arch Dis Child 2000; 82:107-112.

41. Ogden CL, Flegal KM. Changes in terminology for childhood overweight and obesity. Natl Health Stat Rep 2010; 25:1-5.

42. Waterval WA, Scheijen JL, Ortmans-Ploemen MM, Habets-van der Poel $\mathrm{CD}$, Bierau J. Quantitative UPLC-MS/MS analysis of underivatised amino acids in body fluids is a reliable tool for the diagnosis and follow-up of patients with inborn errors of metabolism. Clin Chim Acta 2009; 407:36-42.

43. Stergiou GS, Yiannes NG, Rarra VC. Validation of the Omron 705 IT oscillometric device for home blood pressure measurement in children and adolescents: the Arsakion School Study. Blood Press Monit 2006; $11: 229-234$ 
44. Fang J, Alderman MH. Serum uric acid and cardiovascular mortality the NHANES I epidemiologic follow-up study 1971-1992. National Health and Nutrition Examination Survey. JAMA 2000; 283: 2404-2410.

45. Franklin SS, Larson MG, Khan SA, Wong ND, Leip EP, Kannel WB, Levy D. Does the relation of blood pressure to coronary heart disease risk change with aging? The Framingham Heart Study. Circulation 2001; 103:1245-1249.

46. Li Y, Wei FF, Thijs L, Boggia J, Asayama K, Hansen TW, et al. Ambulatory hypertension subtypes and 24-h systolic and diastolic blood pressure as distinct outcome predictors in 8341 untreated people recruited from 12 populations. Circulation 2014; 130:466-474.

47. Li Y, Wei FF, Wang S, Cheng YB, Wang JG. Cardiovascular risks associated with diastolic blood pressure and isolated diastolic hypertension. Curr Hypertens Rep 2014; 16:489.

48. Corry DB, Eslami P, Yamamoto K, Nyby MD, Makino H, Tuck ML. Uric acid stimulates vascular smooth muscle cell proliferation and oxidative stress via the vascular renin-angiotensin system. J Hypertens 2008; 26:269-275.

49. Zhang JX, Zhang YP, Wu QN, Chen B. Uric acid induces oxidative stress via an activation of the renin-angiotensin system in 3T3-L1 adipocytes. Endocrine 2015; 48:135-142.

\section{Reviewers' Summary Evaluations}

\section{Reviewer 1}

Strengths of the article:

This study shows that in a general population tendency to higher uric acid levels is associated with diastolic blood pressure. It is the first study showing that this phenomenon is related to elevated activity of xanthine oxidase.

Weaknesses of the article: the weak point is lack of analysis of potential associations between xanthine oxidase activity and subclinical arterial injury or oxidative stress.
50. Landmesser U, Spiekermann S, Preuss C, Sorrentino S, Fischer D, Manes $\mathrm{C}$, et al. Angiotensin II induces endothelial xanthine oxidase activation: role for endothelial dysfunction in patients with coronary disease. Arterioscler Thromb Vasc Biol 2007; 27:943-948.

51. Lande MB, Kupferman JC. Pediatric hypertension: the year in review. Clin Pediatr (Phila) 2014; 53:315-319.

52. Flynn JT. Hypertension in the young: epidemiology, sequelae and therapy. Nephrol Dial Transplant 2009; 24:370-375.

53. Intengan HD, Schiffrin EL. Vascular remodeling in hypertension: roles of apoptosis, inflammation, and fibrosis. Hypertension 2001; 38 (3 Pt 2): 581-587.

54. Mulvany MJ. Vascular remodelling of resistance vessels: can we define this? Cardiovasc Res 1999; 41:9-13.

55. Ishikawa J, Ishikawa Y, Edmondson D, Pickering TG, Schwartz JE. Age and the difference between awake ambulatory blood pressure and office blood pressure: a meta-analysis. Blood Press Monit 2011; 16:159-167.

56. Stergiou GS, Ntineri A, Kollias A, Destounis A, Nasothimiou E, Roussias L. Changing relationship among clinic, home, and ambulatory blood pressure with increasing age. J Am Soc Hypertens 2015; 9:544-552.

57. Lurbe E, Thijs L, Redón J, Alvarez V, Tacons J, Staessen J. Diurnal blood pressure curve in children and adolescents. J Hypertens 1996; 14:41-46.

\section{Reviewer 2}

The study is the first one in which, using repeated blood pressure measurements, the association between blood pressure and several ratios of purine metabolites, as proxies for an increased $\mathrm{XO}$ activity in the vasculature, was assessed. The results showed that higher uric acid/xanthine and xanthine/hypoxanthine ratios were associated with higher DBP z-scores in children at a mean age of 7 years. The weaknesses are related to the cross-sectional design, to the fact that blood samples to determine the purine metabolites were only collected once, and to the relatively small magnitude of blood pressure change that is clinically not relevant during childhood. 